\title{
Knowledge Imperialism and Intellectual Capital Formation: A Critical Analysis of Colonial Policies on Educational Development in Sub-Saharan Africa
}

\author{
Adebısı, Moses Adesola \\ Department of Sociology, Faculty of Social Sciences, University of Ilorin, \\ PMB 1515, Ilorin, Kwara State, Nigerıa \\ Email:masbisi@yahoo.com
}

\author{
Doi:10.5901/mjss.2014.v5n4p567
}

\section{Abstract}

\begin{abstract}
The paper examines the interconnections between intellectual capital formation or development in sub- Saharan Africa and its colonial historical antecedents. The historical epochs of the region in its relations with the West manifested by colonialism, neocolonialism and imperialism, tend to have hallo effects on the level of intellectual capital formation, as far as the development of the knowledge industries, which is concerned with the production and distribution of ideas and information rather than goods and services, are concerned. It begins with a statistical presentation and analysis of the state of intellectual capital formation in Africa with the state of information and communication technology as a case study for measurement. The paper argues that the technological backwardness of Africa cannot be divorced from its historical antecedents and relationships. What is the relationship between colonial educational systems and the state of technological development of Africa? Is the culture of 'technological apartheid' a product of deliberate bureaucratic policies dating back to the colonial era? Is the dependent relationship between Africa and the West in post-colonial era related to the consciously and deliberately established educational, socio-cultural, political and bureaucratic structures of the colonial era? Is Africa a victim of its own inherent and internal contradictions as a result of its relationships with the major hegemonic power centres of Europe and America? The paper concludes by tabling the options before Africa in a scenario where global power play has positioned African countries in a delicately complex economic and political matrix dominated by powerful actors with huge social, cultural, political and technological advantages.
\end{abstract}

Keywords: knowledge, colonial education, knowledge industries, technological innovation, intellectual capital, Imperialism.

\section{Introduction}

\subsection{Technological innovation and the globalization of knowledge and knowledge industries}

Technological innovations and advancements in entrepreneurial development have taken the world to the zenith of human progress and economic prosperity. The advent of industrial revolution in England in the $18^{\text {th }}$ century set in motion an irreversible phenomenal progression in the field of science and technology and this has facilitated the pace of information and data processing, which includes data use, storage, retrieval and management. Today, the computer systems have world-wide application and impact. Therefore, it is easy today for anybody connected to the internet to access virtual data on any topic at any location on the planet or extra-planetary locations.

However, the technological infrastructure existent in Africa, especially in the sub-Saharan region is poor and far below world standards. In the area of telecommunication and human skills required to operate them for instance, the region lag behind the rest of the world. According to Castells (2008:92-94), 'there are more telephone lines in Manhattan or Tokyo than in the whole of Sub-Saharan Africa'. He states further that in 1991, there was only one telephone line per 100 people in Africa, as compared to about 2.3 for all developing countries or 37.2 people in the industrialized world. By 1994, Castells shows that the existing telephone lines in Africa accounted for only a meager 2 percent of the world total. By 1995, Castells found out that half of the countries in Africa had no internet connection and according to him, Africa remains "the switched-off region of the world". However, by 1996, some 22 countries in Africa had had their capital cities connected to the internet, but with only Senegal having connection outside Dakar, its capital city, concludes Castells. Odedra et al (1993:1-2), quoted by Castells lamented on the poor state of information technology, infrastructure and skills in Sub-Saharan Africa thus: 
consulting, and at all operational levels, from basic use to mangement. Most countries lack the educational and training facilities needed to help people acquire the proper skills. The few training centers that do exist have not been able to keep up with demand. Only a handful of countries such as Nigeria, Malawi and Zimbabwe have universities that offer computer science degrees. The programs available in other countries are mainly diplomas and certificates. As a result of unskilled and untrained workforce, use organizations are forced to hire expatriate staff, who in turn lack knowledge about local organizations and thus design poor systems.

\subsection{The status of information and communication technology in Sub-Saharan Africa today}

The situation of information and communication technology however improved significantly in sub-Saharan Africa at the tune of the last century. This was facilitated by the increasing impact of globalization. Two major events caused this development: In 2000, as the Soviet Union disintegrated, China and India joined the World Trade Organization, WTO. Popularity in the use of the internet for economic, social and political transactions globalized communication among individuals and organizations across the world. With the invention of Global Systeme Mobile,GSM, teledensity increased, and millions were connected by phone through the internet for the first time in Africa. Consequently, telephone rate per capital improved sharply.

According the "Internet World Stats" (www.internetworldstats.htm, 2011), Africa with a population of about 1.04 billion controls only about 13.5 per cent of the world internet usage by 2011, from the 2 percent of world total in 1994. Growth in internet usage grew from about 4.51 million in December 2000 to about 139.9 million by 2011. This represents an increase of about 2,988.4 per cent within this period. From the same source, Nigeria recorded the highest internet users in Africa with a figure put at 45 million, which makes it the fastest growing internet enabled country in Africa ( as reported by a Nigerian daily, The Guardian of Wednesday, February 15, 2012). The study further shows that 'with 11.4 per cent internet penetration compared with a world average of 30.2 per cent, Nigeria, with a population estimate of about 162 million (HDI, 2011), had the most internet users of 45 million by the end of 2011. Egypt is second to Nigeria with 20.1 million; Morocco, 13.2 million; South Africa, 6.8 million and Zimbabwe coming fifth with a modest figure of 1.5 million internet users.

Similarly, the rate of facebook users has been on the rise in Africa. For instance, out of the 139.9 million internet users in Africa, 37.7 million had facebook accounts with the following breakdown: Egypt with a population of 82 million has the highest number of internet users with facebook accounts put at over 9 million; South Africa is second 4.8 million and Nigeria at 4.3 million in the third position. The report also listed those countries at the lowest point of internet users in Africa as follows: Equatorial Guinea $(14,400)$, Liberia $(20,000)$, Comoros $(24,000)$, Djibouti $(58,000)$, and Mauritania $(75,000)$ among others.

Meanwhile, the global picture of internet usage shows that Asia with a population estimate at about 3.88 billion had within about an 11 year period grew its internet user base from about 114.3 million in 2000 to around 1.02 billion by the end of 2011, representing some 26.2 per cent of the penetration percentage per population, reports The Guardian. The survey further revealed that the continent of Europe with a population of about 816.4 million people grew its internet user base from 105 million to over 500 million between 2000 and 2011, with about 61.3 percentage penetration per population or a growth rate of about 376.4 per cent within 11 years. The statistics for North America is similar to that of Europe. With a population figure estimated at about 347.4 million it recorded a 152.6 per cent growth in internet usage within the period under review, as its internet users moved from 108.1 million in 2000 to about 273.1 million within 11 year period. The penetration rate per population is put at 78.6 per cent. The growth rate figures for the Middle East according to the survey shows that in a population of about 216.3 million, it grew its internet user base from 3.3 million in 2000 to about 77 million by year 2011. This represents a 35.4 per cent penetration per population. The survey further shows that for Oceania and Australia, having a combined population put at about 35.4 million, internet users grew from 7.6 million to about 23.9 million within 11 years (2000-2011), a per cent penetration per population of about 67.5 percent. Finally, the survey reports that within the period under review (2000-2011), global internet users increase from about 360.9 million to about 2.27 billion between 2000 and 2011, representing about 528.1 per cent growth rate and about 32.7 per cent penetration per population.

The foregoing statistical data and analyses present a world-wide geographical distributional fact file of internet usage which will of course reflect its growth patterns and impact on intellectual capital formation and development in subSaharan Africa. In this Information Age, knowledge workers represent a crop of highly paid elite whose knowledge shape and continue to shape the future organizations in the knowledge industries. According to Andrew Carnegie,"The only irreplaceable capital an organization possesses is the knowledge and ability of its people. The productivity of that capital depends on how effectively people share their competence with those who can use it."(Quoted in Steward, 1999: 128). 
What then is knowledge? Our definitional guide is taken from Oxford Advanced Learner's Dictionary (2000: 658). Two basic definitions are provided: 1."The information, understanding and skills that you gain through education or experience". 2. The state of knowing about a particular fact or situation". From these definitions, it is clear that knowledge constitutes an important factor of production that helps to increase the capital value of labour in the industries.

\section{Theoretical Framework}

The Dependency School of Thought and the World System Theory perhaps, represent the best analytical framework for understanding the impact of European colonial and imperial conquest and control of African lands, its peoples and resources. Both perspectives are agreed that global inequalities are to be understood in relation to the nature of the relationships that existed between the West and the Rest, in terms of established structures of unequal exchange between the two. Andre Gunder Frank and Immanuel Wallerstein are the chief exponents of these perspectives. Frank's dependency thesis is centered on the argument that the incorporation of the third world into the global capitalist system dominated by the hegemonic powers of America and Europe had created underdevelopment in the third world. The relationship that existed was characterized by what he calls "unequal exchange" due to centuries of slavery and slave trade, economic pillage and military and political conquests, the kind of core -periphery relations, in which the former provided the latter with ready and palpable sources of exploitation, such as raw materials, market outlets and territorial possessions. This colonial legacy of dependence was carried forward to the post-colonial era during which these countries depended highly on investments from their former and highly developed colonial masters.

The main thesis of dependency theorists rest on the empirically verifiable assertion that Africa's level of development peaked when it had the least contact with the West and vice versa. This development informs Onimode's position that the "the major factors that have forced Africa into the periphery of world economy have been those of the perverse international capitalist division of labour...the single dominant mechanism that has generated unequal development in the world"(Onimode, 2000:78). In the same vein and at another level, Awolowo (1976:26) states that the period of European conquest, rule and plunder left the Africans in a situation he describes as "morally debased, mentally befogged, psychologically benighted, timid and docile, were lacking in initiative, and devoid of self-confidence and of elevating aspirations". The positions of Onimode and Awolowo above rightly add credence to Nnoli's (1980:43) statement that exploitation was central to the cardinal objectives of colonialism. In fact, Nnoli quotes a British official who aptly describes the main objective of British colonialism as "one of exploitation and development for the people of Britain" (Nnoli, quoting H.S.Scott, 1938).

\section{Colonial Educational Philosophy and Policies in Africa}

The geographical patterns of internet usage no doubt reflect the dominance structure of knowledge production and distribution, based on western intellectual and technological apartheid, deliberately designed, developed and spread by its educational, cultural, economic and political institutions. According to Oliver Richmond, in a paper presented at the University of Gothenburg's Centre for Globalization and Development, GCGD (2011), one of the unwritten impacts of British colonialism on education is that whole disciplines were deliberately created and developed at British universities to support colonialism and imperialism. The colonial educational policies were based on the principle of 'FOUR Rs': Reading, Religion, (w)Riting and (a)Rithmetic. The missionary societies of the West who came on an evangelizing mission introduced education with the establishment of mission schools. These schools provided basic education that was useful only for the colonial bureaucratic and administrative needs. Some of the early educational institutions such as Fourah Bay College in Freetown, Sierra Leone, and the University College, Ibadan, Nigeria (now University of Ibadan), offered courses such as classics, commerce, religion, history, etc, that had no direct significance for the much needed requirements for scientific and technological education and development in Africa. Therefore, colonial educational policies were not designed to meet the scientific and technological needs of the Africans. Basic education was required for the spread of Christianity, simple administrative structure of control for the economic exploitation of the Africans, through obnoxious and repressive policies of taxation and direct pillage of economic resources. There is a high degree of congruency amongst scholars on the negative impact of colonialism and imperialism on the development of technological education in Africa. The primary objective or focus of colonialism was essentially economic exploitation. However, achieving this objective fully necessitated formal subjugation and control in virtually all ramifications- social, cultural, political and of course military. Educational institutions were established mainly to provide the needed avenues for cultural enslavement and psychological immersion of the natives into the western value systems and ideological 
pathways. France's policy of assimilation was a ruse for cultural imperialism as it was designed to supplant African values systems with France's in the manner described above. School curricula reflected largely European social and cultural values regarded as the standard yardsticks by which other non-western values were measured. Hence, the colonial rulers failed to accord indigenous knowledge and socio-cultural values any serious recognition. The alleged nonrecognition of indigenous knowledge is central to Cristina Rojas's paper on globalization at an international conference in Sweden (November 22-23, 2011). According to Rojas, the creation of the concept of the indigenous was a major effect of Spanish colonialism in Latin America, with particular emphasis on Bolivia. She centres her argument on what she calls 'knowledge coloniality', arguing that the Spanish rulers and by implication their settler communities failed to recognize the indigenous knowledge of the colonized peoples, especially in Bolivia with thirty-six different ethnic groups. The negative construction of the 'indigenous' often created tension and conflicts between the indigenous peoples and the Spanish settlers. The policy of non-recognition of indigenous knowledge and rights informed the colonial policies of educational exclusion and backwardness particularly in the area of intellectual and human capital development.

\title{
4. Colonial Education: For Development or Underdevelopment?
}

The quality and quantity of education provided in colonial Africa has been debated severally at different places and fora. Africanists and writers on Africa are largely in agreement on the paucity of the quality and quantity of education and scientific training that were provided by the colonial authorities. Rodney's graphic accounts represent a sorry case in the study of relative deprivation under colonial rule and exploitation of African societies and territories. According to Rodney (1972: 293), "a European-type of school system hardly operated during the first forty years or so of colonialism. In that period, missionaries gave schooling for their own Christianizing purposes, and it was in the 1920's that the colonizing powers carried out a series of investigations into educational possibilities in Africa". The British, based on Rodney's account, made belated effort at establishing schools for the Africans under the guise of paucity of funds. For instance, the Colonial Office in London issued the following statement in respect of the demands for educational opportunities in Northern Rhodesia: "Until more money becomes available for the building of schools, no rapid progress can be expected and the practical prospects of providing full primary education for all children remains fairly remote".(ibid.,p.294). The point being made here is that the establishment of colonial educational infrastructure was based on a 'systematic and measured' policy, obviously characterized by relative deprivation when compared with what was in place Europe at the time. The following statistics of school enrolments in the colonies shows the extent of what Walter Rodney calls quantitative limitation as was imposed by the colonialists:

\begin{abstract}
In the whole of French Equatorial Africa (Chad, Central African Republic, Gabon and Congo Brazzaville), there were only 22,000 pupils enrolled in 1938 and that represented quite a jump over figures for the preceding five years. In 1938, the French provided education for 77,000 pupils in French West Africa, with a population of at least 15 million. A very illuminating fact that should be noted is that in 1945 there were more than 80,000 students attending independent Islamic schools in French West Africa-a number not far from those attending French-built schools by that date. (Rodney, ibid, p. 295).
\end{abstract}

Writing on the impact of colonial legacy on development in the developing countries, Todaro and Smith (2009: 68) observes that "institutions created during the colonial period often had pernicious effects on development that in many cases have persisted to the present day". The pre-occupation of the colonialists with slavery and later forced labour led to monumental neglect of other important sectors such as human capital development. According to these authors, inequality was extreme in these developing countries and "the result has been less movement toward democratic institutions, less investment in public goods, and less widespread human capital (education, skills, and health)" (Todaro and Smith, 2009: 68). The consequences of this colonial legacy can be seen in the area of underdevelopment and perpetual economic and technological dependence on these former colonial masters even till today. In the Nigerian case, the British administered the north and south of Nigeria in different ways: the policy of Indirect Rule enabled the colonial administrator, especially under Sir Fredrick Lord Lugard, who became the Governor-General of Nigeria in 1900, to rule Nigeria under different policies. As Oyovbaire (1985: 34) points out, under the indirect rule policy, the northern emirates were shielded from the activities of the Christian missionaries in the area of spreading Christianity, western education and civilization or what he calls 'European cultural traits'. Today, the wide disparity between the northern and southern parts of Nigeria in the area of educational development can be directly linked to the negative impacts of colonial legacies as bequeathed by the British.

In principle, while the colonialists subscribed to a developmental policy in the colonies, their hypocrisies were 
underlined by the practical manifestations of Establishment policies that were implemented on the ground. According to Buah (1977: 128), Lord Lugard, the acclaimed author and chief promoter of the policy of indirect rule, published his famous book, The Dual Mandate in British Tropical Africa, in 1922, in which he explained the double mission of the colonial masters in Africa as to "develop the economic resources of Africa largely for the benefit of the home country, and were at the same time to promote the advancement of the African people morally, educationally and economically". The following extract by Buah explains the core mission or objectives of Lugard's Dual Mandate:

Europe is in Africa for the mutual benefit of her own industrial classes and of the Native races in their progress to a higher plane; the benefit can be made reciprocal, and it is the aim and desire of civilized administration to fulfill this dual mandate. On the other hand, the abounding wealth of the tropical regions of the earth must be developed and used for the benefit of mankind; on the other hand, an obligation rests on the controlling power, not only to safeguard the material rights of the natives, but to promote their moral and educational progress.(cf: F.K. Buah, 1977: 128).

However, the implementation of the so-called dual mandate was pursued via a policy of reckless exploitation of the human and material resources of Africa for the benefit of the so-called industrial classes of Britain and its American and European allies. Support data are well-documented in the literature by different authors (Rodney, 1972; Lenin, 1976; Frank, 1978; Amin, 1976; Onimode, 2000; Castells, 2000; and Wallerstein, 1972, amongst others). While the Portuguese regarded the colonies as provinces of metropolitan Portugal, the French, in their policy of assimilation tended to develop their colonies in line with French culture and civilization. The German on the other hand ruled their colonial territories ruthlessly with an iron fisted hand. Germany's colonial rule of South West Africa (now Namibia) has gone on record as one of colonialism's worst cases with racism, imprisonment, death and economic plunder as its major hallmarks. European colonialism deliberately created a culture of technological and economic dependence in Africa through their policies of neglect and underdevelopment of these vital sectors. This is the major cause of low intellectual or human capital formation and development in Africa.

\section{Conclusion}

The extent of the development of knowledge industries for the production of intellectual and human capital in the subSaharan region today reflects to a large extent its relationship externalities and colonial antecedents. Centuries of precolonial and colonial contacts between the region and the West, dating back to 1444, represented a period of unbridled and unmitigated disaster, characterized by reckless exploitation of its material and human resources, institutional and cultural disarticulation, slavery, death and plunder. The second phase of a disastrous relationship began with the neocolonial period in which former colonial powers of Europe in a conspiratorial alliance with imperial America (The USA) subjected the countries of Africa to political, economic and military control. Hence, Euro-American hegemonic stranglehold on the economies and societies of the developing countries in general constitute a major obstacle for the scientific and technological development of these countries, as result of excessive dependence on these powerful advanced countries for investment capital for their economic and technological development. To maintain control in these countries, there is the need to create a local crop of comprador elite of leaders who will facilitate the exploitation process. Thus the ascendancy of corrupt and inept leaders and governments that are supported by these hegemonic powers, such as Mobutu's Zaire (now Democratic Republic of Congo) supported by America and the West, and the successive predative, corrupt and inefficient military and civilian governments in Nigeria, for example. The foregoing scenario endures given the fact during the period of contact with and control by the West, the development, through the establishment of schools and the teaching of needed educational and scientific curricula, especially at institutions of higher learning, such as universities and polytechnics, was not a priority of the colonial authorities, as evidently manifested in Lugard's Dual Mandate. As stated by Awolowo (1976:18-19), Africa was about two thousand years behind the West in 1444 when the Portuguese 'blazed the trail into Africa', importing 'slaves and gold dust' from Africa to Portugal. Finally, the damage done by colonialism to educational development in Africa is incalculable, given the technological gap that exists between it and Europe or the West in general. Coupled with the myriads of social, economic and political problems facing the region, it has a long way to go to get out of the doldrums. The warning of De Soto (2000: 2) that "The triumph of capitalism only in the West could be a recipe for economic and political disaster", must be given serious attention if the technological gap is to be closed. 


\section{References}

Amin, Samir. (1976). Unequal Development: An Essay on the Social Formations of Peripheral Capitalism. New York: Monthly Review Press.

Andrain, Charles F. and Apter, David E. (1995). Political Protest and Social Change: Analyzing Politics. London: Macmillan Press Ltd.

Awolowo, Obafemi. (1976). The Problems of Africa: The Need for Ideological Reappraisal. Kwame Nkrumah Memorial Lectures. First Series. University of Cape Coast, Republic of Ghana.

Bodley, John H. (1975). Victims of Progress. Menlo Park, California: Cummings Publishing Company, Inc.

Buah, F.K. (1977). West Africa since AD 1000. Book Two: The People and Outsiders. London: Macmillan Education Limited.

Castells, Manuel. (2000). End of Millennium: The Information Age: Economy, Society and Culture. Second Edition; Volume III. Oxford: Blackwell Publishing.

De Soto, Hernando. (2000). The Mystery of Capital: Why Capitalism Triumphs in the West and Fails Everywhere Else. New York: Basic Books.

Drucker, Peter. (1969). The Age of Discontinuity: Guidelines to our Changing Society. Management Series. London: Pan Books Ltd.

Frank, Andre Gunder. (1978). Dependent Accumulation and Underdevelopment. London: Macmillan.

Giddens, Anthony. (2009). The Consequences of Modernity. Cambridge: The Polity Press.

Hands, Gill. (2010). Marx: The Key Ideas. Teach Yourself. London: Hodder Education.

Internet World Stats. (2011). Internet Users in the World by Geographic Regions-2011. (www.internetworldstats.com/stats.htm); published by THE GUARDIAN (Nigeria), Wednesday, February 15, 2012.

Lenin, Vladimir Ilyanov. (1976). Imperialism: The Highest Stage of Capitalism.

Nnoli, Okwudiba. (1980). Ethnic Politics in Nigeria. Enugu: Fourth Dimension Publishing Co. Ltd.

Odedra, Mayuri et al, (1993). "Sub-Saharan Africa: a technological desert," Communications of the ACM, 36(2) 25-9.

Onimode, Bade. (2000). Africa in the World of the 21 $1^{\text {st }}$ Century. Ibadan: Ibadan University Press.

Oxford Advanced Learner's Dictionary. 6th Edition, 2000.

Oyovbaire, Egite S. (1985). Federalism in Nigeria. London: Macmillan Publishers. (Macmillan International College Edition)

Rodney, Walter. (1972). How Europe Underdeveloped Africa. Abuja: Panaf Publishing. 2009 Edition.

Scott, H.S. (1938). "The development of the Education of the African in Relation to Western Contact," in The Year Book of Education. London: Evans Bros.

Steward, Thomas A. (1999). Intellectual Capital: The New Wealth of Organizations. New York: Currency Doubleday.

Todaro Michael P. and Smith, Stephen C. (2009). Economic Development. Tenth Edition. New York: Addison Wesley.

Wallerstein, Immanuel. (1974). The Modern World System. New York: Academy Press. 